\title{
S.J.P. Kruger and the Transvaal Hardliners on Race Policies and Practices in the Early 1870s*
}

\author{
J.S. BERGH \\ University of Pretoria
}

At the beginning of the 1870 s, two distinctive approaches with regard to race relations among white settlers in the Transvaal, namely moderate and hardline, can be detected.1 Both operated within the realm of the white-supremacy mentality of that period. As the American historian J.W. Cell argues in his book on the origins of segregation in South Africa and the American South, white supremacy still represented the dominant mindset even after the turn of the century and that 'cooperation between Boer and Briton depended on the maintenance of white supremacy' at that stage.2 Within this frame of reference, the distinction between moderates and hardliners can perhaps best be described as one between those exhibiting more compassionate and sympathetic leanings with regard to Africans, in contrast to those displaying more inflexible and uncompromising attitudes.

This difference was emphasised at a significant period of transition, when African labour became less available and when Afrikaner farmers were making the change to a mode of farming that was more market-orientated and labour-intensive. It will be argued that the regional, political and economic context contributed to the different approaches of hardliners and moderates. Hardliners were, for example, more prominent owners of land and were to a larger degree dependent on the availability of African labour than the moderates, and their inflexible attitude in this regard could partly be ascribed to this. S.J.P. Kruger was a substantial owner of land with extensive agricultural production (see below), and it seems that at least one historian is of the opinion that he should unquestionably be regarded as a hardliner. 3 However, this article argues that Kruger's attitudes and activities were significantly different from those of the hardliners. A systematic re-evaluation of this prominent historical figure is required, which takes more careful account of how his understanding of the historical context and environment influenced his actions and ideas. Most previous evaluations of Kruger miss important evidence, tend to give one-sided interpretations and do not give adequate attention to his role as entrepreneur and moderniser. In the course of more than a century, individual authors have offered radically different assessments of Kruger and his points of view.4 While publications such as those of Stanley Trapido, Peter Delius, Roger Wagner, Timothy Keegan, A.J. Christopher, F.J. Potgieter and Willem Stals5 shed valuable light on the environment, structures and trends of the pre-industrial Transvaal in the 1860s and 1870s, biographies of Kruger - as well as other publications that focus on him - seem not to take this into consideration sufficiently in their analyses, and put perhaps too much emphasis on personal traits. 6 However, historians are certainly now better positioned to break away from the limitations of the cultural, racial and ideological prejudices of the nineteenth and twentieth centuries concerning Kruger and to evaluate him more comprehensively, taking into account essential historical context. In this re-evaluation, adequate consideration should also be given to the complex and dynamic relations between Africans and whites in the preindustrial period, as well as to the variety of perceptions and attitudes in both communities. Simplified and undifferentiated versions of white or black opinions, impressions and alleged brutality should no longer be tolerated.

A source publication on the important 1871 Transvaal Commission on African Labour has recently been released.7 Although those who testified before the Commission and the correspondence considered by it was to a large degree from the central districts of the South African Republic, the documents of this Commission can substantially enable researchers to grasp more fully the complicated nature of relations between Boer and African communities, as well as the divergent points of view within each of them. The documents also contain, inter alia, the important testimony of Kruger, some of his correspondence, as well as his participation in the debate when the report of the Commission was tabled in the Volksraad. Very few historians have been aware of these documents, which are concealed among the supplementary correspondence of the State Secretary for 1871 in the Transvaal Archives. Those who were aware of the existence of these documents have only utilised them to a very limited extent.8 
As has been suggested above, the hardline and moderate approaches of the 1870s manifested themselves in various arenas of interaction between white settlers and Africans. The article will discuss labour relations in this period, as well as attitudes to land and to Africans in the context of a transforming political and economic situation, and will pay particular attention to Kruger's role.

White farmers had depended on African labour for some time, but several factors contributed to a growing demand for labour from an early stage (see below). The commencement of the mineral revolution at the end of the 1860s on the nearby diamond fields was, however, the most striking development in this regard. The Transvaal authorities attempted in a number of ways to secure the services of African labourers for white farmers. In the 1858 'Guidelines to Field-Cornets', it was, for example, stipulated that those Africans who did not fall under a kgosi (chief) were compelled to report to a field-cornet so as to make their labour available to white farmers.9 This was followed by the comprehensive ordinance of November 1864 on matters such as the provision of labour by Africans, their liability for taxation and their trading in and carrying of firearms. These stipulations were expanded on and consolidated in a law of 1866, which was superseded by Law No. 9 of 1870.10 The availability of African labour to white farmers was specifically addressed in articles 15, 16 and 17 of Law No. 9 of 1870.

Article 15 articulated the principle that Africans should pay taxes for the 'privileges and protection' that they enjoyed, 'in this way making them liable to service to white residents'. By means of a further distinction in article 16 between the rates of taxation imposed on those Africans who were 'in the service of citizens ... and living with these citizens on their farms', those who were 'in the service of their masters but do not live with their masters on the farm', and those 'who are not serving', in order to favour the first two categories, greater pressure was put on Africans to become labourers on white farms. In terms of article 17, those farmers who had African villages on their farms were entitled to the labour of at least five of these households. Africans were, however, allowed to 'hire themselves out to whatever person they wish'. Those Africans who were found guilty of contravening the pass laws (article 4 and 23) and those 'who may wish to settle or have settled in this Republic for the safety of their persons and possessions' (article 13), were compelled to conclude labour contracts with farmers.11

Few, if any, of the white farmers would have argued in principle against the stipulations of Law No. 9 of 1870 and the labour practices that emanated from it, since it was impossible for them to carry on with their farming activities effectively without African labour. This situation is evident from the large number of petitions submitted by farmers in various districts of the Transvaal to the Volksraad in the late 1860s, complaining about the lack of subservience shown by Africans.12 Even missionaries, such as Alexander Merensky of the Berlin Mission Society, regarded it as 'not to be unfair to require of the young unmarried people that every one of them should serve a burgher of the country against remuneration for a certain period of the year (say for six months). This would be a measure that would serve for the civilisation of the natives and the benefits of the burghers.' 13

One can identify various factors that contributed to the apparent difficulties of white farmers to obtain an adequate labour force at the end of the 1860s. African labourers were, for example, to an increasing extent drawn by the more attractive remuneration and availability of firearms on the nearby diamond fields. In 1871, Commandant S.T. Prinsloo testified that African labourers in his vicinity "have left in their hundreds for the diamond fields'.14 By the end of the 1870s, 1000 or more African labourers moved through Pretoria to the diamond fields per month.15

Another factor that increased the demand on the Transvaal African labour pool was the growing number of white settlers. In contrast to 1839 , when only a small number of whites applied for farms, 16 a white population of approximately 29000 was present in the Transvaal by 1873.17

The transformation of production on white farms to a more labour-intensive marketorientated mode of farming in this period also contributed to labour demands. The flourishing market for farm products on the diamond fields must have been an important stimulus in this regard. But this should not be seen in isolation. Various town markets had in the meantime 
also developed. It is, for example, known that from at least the 1850 s there was a sizeable market in Potchefstroom. From August 1860, there was a market in the new town of Pretoria every morning. It was also stipulated in the regulations for towns of 1865 that every town must keep a market every morning, except on Sundays and festive days.18 S.J.P. Kruger's largescale farming activities on his farms at Pilanesberg and in the vicinity of Rustenburg 19 were clearly aimed at producing a surplus for the markets. By 1867, even African peasants in the vicinity of Pretoria brought agricultural products to the market.20 This is an interesting parallel with what Colin Bundy demonstrates with regard to the response of eastern Cape African peasants in the mid-nineteenth century to new markets in that vicinity.21

The developing towns in the Transvaal also generated a demand for African labour, in competition with the white farmers. By way of illustrating this point, in the small town of Pretoria various state departments required from the 1850 s and 1860 s African labourers to serve as police constables,22 mail carriers and maintainers of roads.23 Private institutions in Pretoria required African labourers when the church was built in 1866,24 or at the brick-works 25 and the quarry. 26

But the white inhabitants of the Transvaal were deeply divided in their assessment and perception of African labour and labourers, as well as over the interpretation and implementation of some aspects of Law No. 9 of 1870. On the one hand, there was the more moderate group, including Landdrost P.J. van Staden of Rustenburg, Landdrost W. Skinner of Pretoria, Public Prosecutor O.C. Weeber of Pretoria, as well as some of the field-cornets such as J.L. Jansen van Rensburg of the Hex River Ward and D.J. van der Merwe of Rustenburg town, and certain missionaries.27 On the other hand, if we do not take Commandant-General S.J.P. Kruger into consideration for the moment - since it will be argued later that his position was more complicated - there were the so-called hardliners, including Commandant S.T. Prinsloo of the District of Pretoria and Field-Cornets T. Erasmus of the Apies River Ward, H.P. Malan of the Elands River Ward and G. Brits of the Krokodil River Ward, as well as perhaps some Members of the Volksraad, such as C.N. Smit of Waterberg.28

The moderate group were in favour of African labourers receiving measured treatment. They reported cases of unfair treatment, such as that labourers were sometimes not paid, to the 1871 Transvaal Commission on African Labour and they encouraged labourers to lay charges in this regard. Excessive demands on African labourers were also brought to the attention of the Commission by the moderates, as were cases of harsh treatment. These included the flogging and humiliation of $\mathrm{kgosi}$, as well as of individual African labourers.29 The moderates also interpreted and applied Law No. 9 of 1870 to the advantage of African labourers. Their point of view was that those Africans who were taxed in terms of article 16 at the highest rate (ten shillings) because they were 'not serving' were no longer under an obligation also to hire themselves out as labourers. 30

The hardliners were much more severe and negative in their evaluation of Africans and African labour, and in their approach to the labour question. For example, Commandant S.T. Prinsloo was of the opinion that '[t]he natives are paid more than they deserve'..31 FieldCornet T. Erasmus told the 1871 Commission: 'I think the more harshly a native is treated, the better he will do his duties' and '[m]y idea was to make every native serve a master and have him live on his land and not let him live in kraals'.32 For Field-Cornet H.P. Malan, '[t]he more freedom one gives a native, the worse it is'.33 With reference to the beating of kgosi Kgamanyane Pilane, he said: '[t]he beatings made him less cheeky.' 34 The hardliners were also of the opinion that despite the higher taxes paid by those Africans who were not in the employment of white farmers, such Africans were still liable to render their services as labourers. They even complained that the moderates' lenient interpretation of the law in this regard (that those Africans who paid the highest tax rates were not obliged to serve as labourers) constituted one of the main reasons for the labour problem.35

The points of view and attitude of the hardliners should be evaluated against the background of their dependence on African labour. All of the hardliners who were identified for the purpose of this article were landholders. H.P. Malan owned at least four farms or parts of farms by 1871, when he testified before the 1871 Transvaal Commission on African Labour. 36 T. Erasmus owned three farms by $1871_{37}$ and S.T. Prinsloo and G. Brits one farm each $_{38}$ at that stage. Malan, Erasmus, Prinsloo and Brits were also involved in many more land transactions in the 1850s, 1860s and 1870s.39 At a time when large numbers of African labourers left for the diamond fields, when the growing number of white settlers made 
increased labour demands and when the labour demands per farmer expanded in relation to more market-driven production, farmers must have been very desperate to secure labour. In contrast to this, those moderates who were identified were not dependent on the availability of African labour. Three of them were civil servants - two landdrosts and a public prosecutor. It also appears that the two moderate field-cornets, D.J. van der Merwe for Rustenburg town and J.L. Jansen van Rensburg of the Hex River Ward, did not possess any farms by 1871.40 Landdrost Van Staden owned at least three farms at that stage,41 but he seems to have focused more on land speculation.42 Landdrost Skinner did not own any farms by 1871, and was also actively involved in land speculation.43 The Public Prosecutor, Weeber, bought one farm in the beginning of 1871, but sold it in the same month.44 Skinner and Weeber also seem to have benefited from information which they obtained in their respective positions when they bought the farms Klippan No. 331 and Middelkop No. 332 in the early 1870s, only to later sell it via the attorney C.F. Preller to the Berlin missionary Otto Sachse, who acted on behalf of the Motsha Bakgatla of Andries Maubane.45 Skinner and Weeber must have been well aware of the conflict between the Motsha Bakgatla and a consortium of farmers ('belanghebbers') on whose farms they lived at that stage (see below).

\section{II}

The debate among the white inhabitants of the Transvaal concerning the allocation of land to Africans, and the ownership of land by the latter, took place against the background of widespread dispossession of Africans of their land by white settlers in the three previous decades. This dispossession did not differ much from what had occurred in this regard within European colonies elsewhere in the world. In the case of white settlers in the Transvaal, the process was encouraged by governmental stipulation that white settlers who had settled in the area before 1852 were entitled to two farms per household. Other factors also contributed to this process - inter alia the practice by the Transvaal government of using land grants to get its weak economy off the ground, as well as land speculation by individuals and companies. In some instances, white settlers demarcated land for themselves that included African villages.46 Although the Volksraad provided for the allocation of reserves to Africans in 1853 and 1858, little progress was made in this regard. Also, the Volksraad took a decision in 1855 that Africans were not allowed to receive titles to land. In these circumstances, some African communities, especially in the central districts of the Transvaal, decided to request missionaries to buy land for them with money they obtained on the diamond fields and hold it informally in trust for them. On the other hand, certain white farmers in the District of Pretoria made land available for settlement by African communities in order to secure their labour this was especially necessary in a period when the diamond fields were attracting large numbers of African labourers. 47 However, these processes differed from region to region. In the eastern Transvaal, where a number of chiefdoms were still relatively intact, some white farmers were forced to pay tribute to the kgosi or even to abandon their claims to land.48

The land issue apparently did not spark off such heated differences in opinion between the moderates and hardliners as the labour issue. Most of those who testified before the 1871 Commission were in favour of the settlement of African communities on government land, instead of on the farms of individuals, owing to the many difficulties that were being generated in the last-mentioned instances.49 Only field-cornets T. Erasmus and G. Brits were strongly in favour of distributing African labourers among farmers. Erasmus was of the opinion that '[a]s soon as the natives have their own land ... they will be even less willing to serve'so and Brits that 'if they lived on Gov[ernment] land they would be less willing to serve'.51 Their sentiments were echoed in the Volksraad by the member for Waterberg, C.N. Smit, who 'was against withdrawing natives from all service [diensbaarheid]. He wanted to hear nothing about locations.' 52 This one-sided point of view was, however, quickly dismissed by the member for Pretoria, J.R. Lys: 'Mr. C.N. Smit was in favour of the old system and how had that worked? Where were the native workers?'53

The real debate in the Volksraad, it would seem, was between those who were prepared to make provision for the settlement of African communities only on government land 54 and those who were convinced that it was also necessary to permit African communities to buy land, but only in terms of a trusteeship system under government supervision. The reason G.P. Moodie, the member for Wakkerstroom District, supported the 
latter suggestion was that 'if natives were placed on government land, they would not prove to be good subjects and [he] was in favour of granting natives land rights and giving them the right to purchase themselves'.55 J.C. Preller, member for Bloemhof District, articulated the importance of this to the farmers more clearly: 'He said that to retain native workers, it was essential to give them an interest in land.' 56 I.C. Holsthausen, member for Lydenburg District, also supported this point of view.57 Two other members, J.R. Lys and the chairman of the Volksraad, H.J. Ueckermann, were, however, of the opinion that this privilege should only be granted to 'faithful' Africans.58 The Volksraad eventually accepted the following proposal with a majority of votes:

The Volksraad resolves to approve the recommendation of the Commission under the letter

$A$ and to instruct the government to reserve land or attempt to procure the same, suitable for native locations, if possible divided in the different districts, or for the purchase by native tribes, subject to the provision that they may not dispose of the land in any way other than with the approval of the government, who shall have the right in the case of resale, to again acquire the land preferentially for itself against payment of the original purchase price and the improvements effected and, furthermore, that the residents shall be subject to the laws and provisions already promulgated or still to be promulgated in respect to blacks [kleurlingen].59

III

In their testimonies before the 1871 Commission, at least two of the hardliners, Commandant S.T. Prinsloo and Field-Cornet T. Erasmus, voiced opposition to the possible withdrawal of the Proclamation of 24 March 1858 by State President M.W. Pretorius, in which trade in firearms and ammunition with Africans was forbidden.60 They were supported in the Volksraad by N.J. Grobler, the member for Waterberg, when this issue was debated in that house.61 Bearing in mind the many wars and conflict situations with African communities that the white settlers had encountered in the interior, it is surprising that this was not a more controversial issue. However, the arguments in favour of the scrapping of the proclamation were very convincing, inter alia that it discriminated against those African communities which were loyal to the state, since it was only possible to apply the stipulations of the proclamation to a certain degree with regard to them, but not in the case of the outlying hostile communities; that these loyal African communities were also often called up for commando duties with their guns; that if Africans were permitted to buy firearms in the Transvaal, it would take away their incentive to proceed to the diamond fields in order to obtain guns there, and in that way would also address the labour problems of the farmers; and that the government could benefit substantially from the increased import duty on firearms.62 The 1871 Commission was eventually persuaded by the logic of these arguments and recommended that the proclamation should be repealed.63

One needs, however, to take into consideration that the great majority of those who testified before the 1871 Commission were from the central and southern districts of the Transvaal. No wars or serious skirmishes with African communities had taken place in these areas for some time. Conflict with Africans was to a large degree restricted to the northern and eastern areas, as well as to the western frontier region.64 When the Commission's recommendation was debated in the Volksraad, where representatives from all the districts were present, they dealt with this more cautiously. The Volksraad decided to postpone a decision on this matter until the next year.65

S.J.P. Kruger expressed the opinion to the 1871 Commission that the main reason for the labour problems in the Transvaal was caused by different interpretations of Law No. 9 of 1870 by landdrosts and military officers:

As far as known to me the cause of the disobedience of the natives originated in [the fact] that the officers and Landdrosts together issued orders to the natives, giving divergent interpretations of the Native Act. Some Landdrosts and Public Prosecutors interpreted the Act [as saying] that the native peoples were free of services and the officers that they had to serve. This was the reason for different punishments being given to natives. The natives maintained the interpretation that they were free... I 
think that when it is clearly made known who has the authority, the officers or the Landdrost, they [the natives] will be obedient, but not these two together.66

Kruger interpreted article 16 of Law No. 9 of 1870 to mean that those Africans who had paid the highest tax of ten shillings because they were not employed were still obliged to make themselves available as labourers to farmers. Although at first glance this seems to represent an unjust and inaccurate interpretation of article 16, a close analysis of this article at least gives the impression that his interpretation might have been feasible. The related clause reads as follows: '... the natives who are not serving shall annually pay ten shillings sterling, remaining the natives who paying this tax, shall despite so paying, still remain liable to the government for service ...'.67 Of course this stipulation might have been referring to the Africans' obligation to take part in commandos when needed by the government, for example, but Kruger's interpretation was possible as well. As a farmer and the Commandant-General, he was also deeply aware of the extent of the labour problem and he knew that a serious shortage of African labour could have harmed both the white farming community and the state.

In his capacity as the owner of a number of farms, Kruger concluded various agreements with Africans, especially with Mokgatle Thethe, kgosi of the Bafokeng, and Kgamanyane Pilane, kgosi of the Kgafela Bakgatla. It would appear that he had concluded labour-tenancy and rent-tenancy agreements with regard to some of his farms and that it is also possible that elements of sharecropping could have been present in his agreement with Mokgatle, in connection with the farm Kookfontein (see below).68 Although the missionaries H.L. Gonin and Christof Penzhorn were under the impression that Kruger sometimes did not pay his labourers, they obviously were not aware of the stipulations of, for instance, the labour tenancy agreements concluded with these labourers.69 Kruger, nevertheless, was a strict taskmaster and Africans were sometimes afraid of him.70 In contrast, there is also evidence of Kruger's concern for the African communities and labourers with whom he came into contact, as well for good relations between them. In 1866, for instance, a casual visitor to the Rustenburg area was impressed by the cordial relations between Kruger and Mokgatle Thethe.71 In his evidence before the 1871 commission, Kruger also expressed himself in favour of Africans being allowed to leave for the diamond fields or elsewhere to earn something for themselves abroad ... as the household of a native must also have the time to look after their family as well although he is under contract'.72 To the question whether Africans should be treated 'strictly or not', he responded: 'All subjects of the state must be treated justly and be punished according to their deserts, also having regard to their ignorance ... Fairness to all.'73 It was therefore perhaps not unexpected that Mokgatle contributed $£ 60$ to the travel expenses of Kruger and Jorissen's trip to England after the Annexation of the Transvaal in 1877.74

With regard to the land issue, Kruger was requested by the 1871 Commission to express his opinion as to whether Africans should be given government locations or be allowed to live on private land. He responded:

It would be fortunate if all natives lived with their lords and masters on private farms, but it would not be advisable to force them to do so and it is not good to have large native kraals on private farms where there are hoofd kapiteins. It would be much better that such tribes live on gov[vernment] land.75

His answer to the question '(m)ay natives possess land in their own name?' was that '(t)he natives may not have land in their own name as long as they are still so uncivilised'.76 It is noteworthy that Kruger did not reject the possibility that Africans would eventually be able to 'possess land in their own name', when they were more 'civilised'. As a matter of fact, he was ahead of his time in this respect. He had already approached the Executive Council of the Republic in January 1868 regarding this very issue. On that occasion, the Executive Council decided, apparently on the initiative of Kruger, who was a member, to recommend to the Volksraad that some kind of trusteeship should be introduced. Under this arrangement, it would have been possible for African communities to buy land but then to have it transferred into the name of the Government, who would have acted as the trustee.77 But the Volkraad was not in favour of this arrangement at that stage and referred this matter back to the Executive Council for a report on the feasibility of government reserves for African communities.78 The 1871 Commission merely recommended '[t]hat native tribes must live on government land',79 but in reaction to this, the Volksraad took a decision on that occasion that 
was very similar to the recommendation of the Executive Council which was made in January 186880 (see above).

During the 1871 debate in the Volksraad on this issue, J.R. Lys indirectly accused Kruger, who owned some of the land on which the Bafokeng of Mokgatle Thethe lived, of acquiring land in order to enrich himself, to the detriment of the Bafokeng:

He asked whether Magata [Mokgatle Thethe] still had the farm granted to him by the Government. He [J.R. Lys] said no, speculators took over the farms and later sold these to the detriment of the state. It should not happen again that two or three people enrich themselves in such a manner and he [J.R. Lys] regretted that the Government had not earlier countered such acts and he wished to know what should be done now when the land was lost.81

Kruger responded to this in the following way: 'He felt compelled to defend himself against $\mathrm{Mr}$ [J.R.] Lys because he had bought the land of Magata [Mokgatle Thethe] nearly seventh hand so as not to have the natives oppressed.' 82 Kruger's explanation is borne out by a close analysis of the earliest farm-registers in the Transvaal. In the case of the farm Beerfontein, where Mokgatle's kraal was situated, entry 462 on 30 July 1849 for Zacharias Johannes de Beer describes its location as being 'next to the Magaliesberg on the land (plaats) of the native chief Mogata [Mokgatle]'.83 Similar entries with regard to land on or adjacent to Mokgatle's land - none of them for Kruger - were made in a few other cases as well, with one entry dating back to as early as 1843.84 Kruger was in any case explicitly opposed to the actions of those settlers who had demarcated land for themselves that included the villages of Africans.85 In addition, when Kruger sold the farms Beerfontein and Turfontein to the Hermansburg missionary Christof Penzhorn (on behalf of the Bafokeng) and Saulspoort to the Dutch Reformed Church missionary Henri Gonin (on behalf of the Kgafela Bakgatla) at the end of the 1860s and the beginning of the 1870 s, the right of these communities to live on these farms from generation to generation was specifically guaranteed.86 It must, however, be observed that even after these land transactions Kruger was still in a very favourable position with regard to access to the labour of these communities because of the proximity of some of his remaining farms to them.

As Commandant-General of the Transvaal, Kruger was almost continually involved in conflict with hostile African communities. He was, for example, directly involved in the long drawn-out skirmishes with the Venda of Soutpansberg in this period and the evacuation of Schoemansdal in 1867. At Makapanspoort, the town Piet Potgietersrus was threatened by African communities in that vicinity and was also evacuated in 1870, mainly because of a severe malaria epidemic. In the east, in the neighbourhood of the Leolu Mountains and the Steenkampsberg, the relations between African and white inhabitants were at this stage also tense and various clashes occurred.87 It was therefore not surprising that Kruger held clear-cut opinions on whether the proclamation prohibiting the trade in firearms and ammunition with African communities should be withdrawn or not. He articulated this point of view to the 1871 commission as follows:

For me there is no vision of the future of our state if the [prohibition on the] sale of ammunition be repealed as in our state there are easily 1000 coloured persons [kleurlingen] against one white. We cannot but regard them as the arch-enemies of the whites. If we ourselves help to prepare our enemies to have the opportunities to conquer us, it would be better to hand our country over to them and go away. It is also unpolitical, in my view, for their entire nature is such that as soon as they have that opportunity, they will not allow the whites to stay a day longer in the country. We have sufficient evidence not only in other countries where they were civilised, but later attacked the whites, but even on the western borders where ammunition [sales] have not been prevented, they wish to have a part of our country. My feelings are that if we allow the sale thereof to be permitted, we would be blind and intent upon our own destruction. 88

It is clear that in this statement Kruger was thinking of hostile communities, mostly in the outlying districts, not so much the loyal African communities. Despite this, he attempted a survey of firearms among African communities in the vicinity of Rustenburg in 1866 as well.89 Nevertheless, he must also have been fully aware of the valuable assistance rendered by these loyal African communities in times of war. The Reverend Penzhorn testified, for example, in 1871 that in the Commando against Mapela, 120 Africans from that area were 
armed with firearms.90 During the 1890s, Kruger defended in the Volksraad the practice of providing loyal Africans with guns.91

\section{V}

To understand Kruger's attitude towards Africans and African labour and to put this into perspective against those of the hardliners, it is necessary to consider both the political and economic context of his activities as well as his personality traits.

By 1871, Kruger was the owner of 14 farms or parts of farms in the District of Rustenburg. The hardliner with the most farms, H.P. Malan, owned four farms in this District at that stage. A comparison of the locality of these farms in relation to the local market at Rustenburg reveals, however, a decided advantage to Kruger.

Five of his farms were in the vicinity of that town 92 and another two in that area, Turffontein No. 297 and Beerfontein No. 432, were sold to the Reverend Christof Penzhorn (as trustee for the Bafokeng) at the end of the 1860s and transferred in June 1871.93 Two of Kruger's farms were located in the vicinity of the Elands River,94 three in the immediate vicinity of the Pilanesberg ${ }_{95}$ and the last two to the northwest96 and northeast of Pilanesberg. ${ }_{97}$ In contrast to this, only two of Malan's farms (he owned sections of these farms) were located in the vicinity and to the east of Rustenburg..88 Malan's third farm was to the north of the Elands Riverg9 and the last farm to the northeast of the present Thabazimbi.100 Both Kruger and Malan sold some of their other farms in the years prior to 1871 - Kruger sold 11 farms 101 and Malan four.102 In the years immediately after 1871, Kruger bought another farm in 1872103 and Malan three farms in respectively 1874, 1877 and 1879.104

An analysis of the location of Kruger and Malan's farms with regard to access to African labour reveals a similar situation. Kruger's farms in the vicinity of Rustenburg were strategically situated with regard to the Bafokeng community of Mokgatle Thethe. As a matter of fact, the village of Mokgatle was on Kruger's farm Beerfontein No. 432. Even after Kruger sold Beerfontein and the adjoining farm Turffontein No. 297 in the late 1860s and early 1870s to Christof Penzhorn and the Bafokeng, his farms Boekenhoutfontein No. 336 and Kookfontein No. 337 were still adjacent to the Bafokeng community (see map). Kruger used this favourable location to his advantage and obtained large numbers of labourers in this way - probably mainly on a labour-tenancy basis.105 For his farm Kookfontein No. 337, however, he and the co-owner Nicolaas Theunissen, his brother-in-law, concluded a contract with Mokgatle to cultivate the lands for them and this agreement seems to have contained elements of sharecropping. ${ }_{106}$ On another farm, Kruger and his son Jan had a rent tenancy agreement for part of the farm with Mokgatle.107 Kruger's farms in the vicinity of the Pilanesberg were also very favourably located to gain access to labour from the Kgafela Bakgatla of Kgamanyane Pilane. Kgamanyane's village was on one of Kruger's farms, Saulspoort No. 269, and Kruger also owned three other farms in the immediate vicinity. After Kruger sold Saulspoort in $1869_{108}$ to the Reverend Henri Gonin and the Kgafela Bakgatla, he was still in a strategic position with regard to access to their labour and seems to have utilised it fairly extensively.109 However, when Kgamanyane and most of his followers left the Pilanesberg in the latter half of 1870,110 it must have negatively affected the availability of labour for Kruger and the other farmers in that area.

The two farms Kroonendal No. 177 and Klipfontein No. 538, of which H.P. Malan owned sections in 1871, were located in the area - to the southeast of Rustenburg - and were a little less favourably situated than Kruger's farms with regard to access to the labour of the Bafokeng of Mokgatle at Beerfontein No. 432. The Bafokeng at the Hermannsburg mission station at Kana on the farm Reinkoyalskraal No. 333 on the Hex River were in fact nearer to Malan's farms. His farm Roodebank No. 492 was located relatively near to the Kgafela Bakgatla of Kgamanyane at the Pilanesberg but, again, not in the very favourable position of Kruger's farms. Although Malan was regarded as 'one of the wealthiest cattle farmers' at the time of his death in 1899,111 he was clearly at this stage (1871) still busy finding his feet. The difficulty in obtaining labour could have contributed towards revealing a less attractive side of Malan in his dealings with Africans at this stage of his life - there are indications that even in the 1890s he tended to approach matters where Africans were involved in a harsh way.112 
It is striking that all the hardliners were caught up in incidents of friction and disputes with local African communities in the early 1870 s and even earlier, and that this, as well as the apparent difficulty that at least some of them experienced in securing African labour, could have lead to their 'hardline' approach towards Africans. Both T. Erasmus and S.T. Prinsloo were, for example, involved in the dispute between the Motsha Bakgatla and a consortium of Boers who referred to themselves as 'belanghebbers' (interested parties). The 'belanghebbers' originally concluded a labour tenancy agreement with the kgosi of the Motsha Bakgatla, Moepi Maubane, in 1856. This contract was renewed in November 1870 with his son Maubane Moepi (Andries). In terms of the contract, the 'belanghebbers' made the farm Boschplaats No. 507 and parts of Witgatboom No. 62 and Wynandskraal No. 154 available to the Motsha Bakgatla to live on and to cultivate for their own benefit. In exchange, the Motsha Bakgatla had to provide the 'belanghebbers' with labour. The 'belanghebbers' also agreed to remunerate the Motsha labourers to a certain extent. This arrangement, however, caused considerable friction. The Motsha complained that most of them did not receive remuneration regularly and were not always treated fairly. They also claimed that they had given the 'belanghebbers' 88 head of cattle to buy one of the farms on which they lived. The 'belanghebbers' gave another explanation for this, but this clearly caused great dissatisfaction among the Motsha. At the time of the 1871 Commission, the Motsha wanted to terminate the contract and move to government land.113 On the other side, the 'belanghebbers' were complaining about the lack of subservience on the part of the Motsha.114 S.T. Prinsloo and T. Erasmus were directly involved in the relationship between the 'belanghebbers' and the Motsha. Erasmus was one of the 'belanghebbers' with a share in land where the Motsha lived, 115 and Prinsloo was Field-Cornet and Commandant for that area for a period. Prinsloo referred to instances where he had to fine the Motsha for not providing labour. Those who did not want to pay, or could not pay, received corporal punishment.116 On one occasion, the Motsha reacted very aggressively towards Prinsloo and Erasmus and they 'nearly lost their lives'.117 The Motsha eventually used the Berlin missionary Otto Sachse to buy other land for them in 1873, and they settled there.118

Another hardliner, Gert Brits, was embroiled in an unpleasant incident with Klein Magato, also known as Nicodemus [Molefe? Mmamogale], who was acting kgosi of the Mogopa Bakwena for a while.119 Although most of the Mogopa Bakwena villages seem to have been in the Hex River Ward of Field-Cornet J.L.J. van Rensburg in the District of Rustenburg, some of the villages were located in the Krokodil River Ward of Field-Cornet Brits in the District of Pretoria. A complicating factor in this regard was that Van Rensburg, who was identified as a 'moderate' for the purposes of this article, apparently had enough African communities in his ward to supply the labour demands of the white farmers, whereas Brits's position in this respect appears to have been more desperate. This situation was aggravated with the migration of some of the Mogopa Bakwena from his ward to those of Van Rensburg. Brits responded to this by administering corporal punishment to Klein Magato, even though Klein Magato was at that stage settled in the Hex River Ward. The corporal punishment also caused friction with Van Rensburg and the Landdrost of Rustenburg. 120 According to Brits, the result of the corporal punishment was that he 'obtained more workers than previously'.121

H.P. Malan was undeniably the most prominent of those so-called hardliners who were identified for the purpose of this article. He was also involved in the most important incident of friction with an African community at this time, namely that with Kgamanyane Pilane and his Kgafela Bakgatla followers at Saulspoort, Pilanesberg. Malan testified before the 1871 Transvaal Commission on 3 October 1871 in this regard:

There were also matters that happened between him [Kgamanyane Pilane] and me. The disobedience was considerable. I have never fined him, but once I punished Gamajan [Kgamanyane Pilane] with a beating. The Commandant General had notified me that Gamajan [Kgamanyane Pilane] had been disobedient to the Field-Cornets Nic[olaas] [N.J.] Smit and Gert [S.] Botha. He had sent no workers to them. The Commandant General instructed me to investigate the case and punish the offender. I know of no law giving me the right to give a hoofd kapitein a beating. I have tried to keep this as a means to force the native kapitein into obedience. I am acquainted with the Field-Cornet instructions. I have only beaten him once. Before I was a Field-Cornet, he had already gone away many times. It is not known to me that he had complained about that. It was about the time that the Landdrost collected the taxes. The beating made him less cheeky.122 
Malan's testimony was corroborated by those of Henri Gonin, the Dutch Reformed Church missionary at Saulspoort, on 28 September 1871:

Gamajan [Kgamanyane Pilane] departed about one year ago. He left because he as hoofd kapitein was beaten and was afraid to be beaten again. For the rest the reasons are known to the Government. He was beaten on a farm about $1 \frac{1}{2}$ hours from his kraal. This was in the beginning of April 1870 . The FieldCornet Hercules [H.P.] Malan beat him. Gamajan [Kgamanyane Pilane] told me that he had been beaten up.123

In August 1879, during the British occupation of the Transvaal and when it would have been easier for him to speak his mind, Gonin again referred to this incident:

It was formerly here that the head chieftain of all the natives in this part of the country, Khamayane (the Dutch farmers call him Gamajan) used to live, but nine years ago in consequence of corporal chastisement inflicted upon him at the request of $\mathrm{P}$. Krüger by the former Field Cornet $\mathrm{H}$. Malan he emigrated to Machuli...124

Malan and Gonin's version of this incident is to a certain extent supported by the testimony of Field-Cornet D.J. van der Merwe: 'Gamajan [Kgamanyane Pilane] personally told me before he left that he was the only kapitein who got a beating on the orders of Mr [S.J.P.] Kruger.'125

This incident, as well as other factors, such as a meeting that Kruger planned with the Kgafela Bakgatla for 20 September 1870, and unfounded rumours that their firearms were to be confiscated and their children to be taken from them, eventually led to the migration of Kgamanyane and most of his Kgafela Bakgatla followers in September 1870 to the present Botswana. H.P. Malan and some of the white farmers went after them to persuade them to return, but without success.126 The Transvaal Government also tried to convince them to return. Apart from the essential labour that they supplied in the Pilanesberg region, they had paid between $£ 1000$ and $£ 1200$ taxes annually in the two previous years.127

Kruger, in his official capacity as Commandant-General, was involved in all three of the above incidents of friction between hardliners and African communities. But from the way that he handled these cases, it is clear that in general he did not suffer the same narrowness of vision as the hardliners, and he attempted to work towards compromises.

With regard to the friction between the Motsha Bakgatla and the 'belanghebbers', Kruger convened a meeting of the interested parties on Saturday 17 December 1870 after receiving instructions to this effect from the Executive Council. At the meeting he allowed ample opportunity for the Motsha as well as the 'belanghebbers' to state their respective points of view. During the discussion, it came to his attention that, apart from the contract with the 'belanghebbers', the Motsha had also concluded a labour-tenancy agreement with one of the other neighbouring farmers, Carel Erasmus, to use his farm, but that complications also emerged in their relations. It must have become clear to Kruger that the differences between the Motsha and the 'belanghebbers' were almost irreconcilable. Despite this, Kruger convinced the 'belanghebbers' to negotiate further with the Motsha, 128 although eventually this approach was not successful (see above).

Kruger also tried to arbitrate in the dispute between Field-Cornet Gert Brits and Klein Magato [Molefe? Mmamogale] and the friction it caused with Field-Cornet J.L.J. van Rensburg of the Hex River Ward and the Landdrost of Rustenburg. In a letter of 7 October 1870 to the President and Executive Council, Kruger explained that African communities were, according to an earlier decision of the Military Council (Krygsraad) and for the purpose of making their labour available to white farmers, divided among the various field-cornet wards. In many instances, however, African communities of one ward were allocated to another and the understanding was that field-cornets should not interfere in this arrangement. In cases of friction, the field-cornets concerned should resolve the dispute among themselves or refer the matter to their superiors who should then act in accordance with the laws of the state.129

It was more difficult for Kruger to stay impartial in matters concerning the Kgafela Bakgatla because of his own interest in the land and labour of the Pilanesberg area. It must also be taken into account that until 1869 Kruger owned the farm Saulspoort No. 269, where Kgamanyane and his Kgafela Bakgatla followers were settled and that there apparently was a rent-tenancy or a labourtenancy agreement between them. In 1869, Kruger sold Saulspoort to 
the Reverend Henri Gonin and Kgamanyane.130 Various incidents of friction occurred between Kruger and Kgamanyane. H.P. Malan recalled in 1871 that in the period before he became a field-cornet - that is before 1869 when Kruger was still the owner of Saulspoort - Kruger fined Kgamanyane. According to him, Kruger had also at some stage - possibly also before Malan became a field-cornet - suspended Kgamanyane as kgosi of the Kgafela Bakgatla on account of drunkenness. It must also have been in the period before 1869 that Kruger 'entered into an accord' with Kgamanyane to build a dam on Saulspoort - seemingly as part of their labourtenancy agreement.131

Contrary, therefore, to the assumption of the historian B.M. Mbenga, that the socalled dam project was the reason Kgamanyane and the Kgafela Bakgatla left Saulspoort in 1870 , it is clear that this incident could only have contributed indirectly to their decision. Mbenga's version fails to a large degree to take into consideration the complexity of this matter, tends to simplify motives and personalities, and resorts to racial stereotypes, without giving credit to the range of opinions and attitudes towards Africans within the Afrikaner community in the Transvaal at that time. Kruger appears as an archetypal racist and tyrant in Mbenga's narrative ${ }_{132}$ - even to the extent that Mbenga quotes the very partial observation of W. Mocom, Theophilus Shepstone's legal adviser, that Kruger had 'a countenance denoting extreme obstinancy and also great cruelty' 133 in an attempt to explain Kruger's behaviour. The likelihood that Kruger's labour relations with Kgamanyane and the Kgafela Bakgatla was regulated by a labour-tenancy agreement in a structured way, and various other aspects, are not considered by Mbenga. On the strength of a few interviews that he conducted in 1993 and 1994 with individuals, mainly from Saulspoort, Mbenga came to the conclusion that the 'dam project' and 'forced labour' of the Kgafela Bakgatla for that purpose were the primary causes for the clash between Kruger and Kgamanyane. 134 Oral traditions such as these, which have been transmitted over a period of approximately 120 years, can be problematic and should be corroborated by other, more accurate evidence - especially in cases where only a very few unconnected individuals were consulted.135

Further, Mbenga - on the strength of two additional secondary sources - connects the 'dam project' with the flogging of Kgamanyane in April 1870 ('Kruger then personally flogged the prostrate Kgamanyane') and the migration of the Kgafela 'on 26 April 1870' to the present Botswana. 136 There is, however, an important gap in Mbenga's argument if one takes into account the fact that Kruger sold Saulspoort in 1869 to Gonin and Kgamanyane, and that he would consequently not have been involved in a dam project for himself after that date on this farm; that H.P. Malan admitted that he (and not Kruger) flogged Kgamanyane in April 1870; and that the migration of the Kgafela Bakgatla only took place in September 1870 (see above). The fact that Henri Gonin does not mention the dam project in his correspondence is an indication that it could even have happened before he settled at Saulspoort in August 1866.137

The different interpretations of article 16 of Law No. 9 of 1870 by Kruger and Landdrost P.J. van Staden - respectively that Africans should, irrespective of whether or not they paid the highest rate of taxation (ten shillings), still be obliged to hire themselves out as labourers or whether they were in such a case free not to serve - seems to have eventually played a more important role in creating the necessary circumstances and atmosphere for the flogging incident of April 1870. In his 1871 testimony, H.P. Malan referred to this in the following way:

The Commandant General and the Landdrost of Rustenburg each interpret the Native Act in a different way. By the Commandant General, the natives were told that they had to serve, by the Landdrost they were told they would be free if they paid 10/-. I was not present myself with the collection of the taxes when this happened. It was about three years ago. I was not present myself, but was told by my provisional Field-Cornet Diederik Putter and by people in my ward. There was then a conflict between the Landdrost and the Commandant General. As I was informed, it was in the presence of one native, if there were more present I do not know. It was behind the private native's place. I do not know what the outcome of the conflict was. Gamajan [Kgamanyane Pilane] did not leave immediately after the conflict. He left about one year, two years after that conflict.138

As early as March 1869, the missionary at Saulspoort, Henri Gonin, predicted that if the labour/taxes issue was not resolved, it would cause the Kgafela Bakgatla to migrate: 
Recently the taxes of the natives were collected. They were promised that they will be exempted [from labour obligations] if they pay well. But I think they were deceived because, as far as I can see, they stayed subservient. Also, the way the taxes were collected left much to be desired ... some white people did not hesitate to take advantage of the distress of the natives to buy their sheep, goats and cattle for next to nothing ... I feat that if our Government should not keep their promises to the natives better than they have done thus far, the natives will leave.139

It is noticeable that the April 1870 flogging occurred when Kgamanyane received conflicting orders from the Landdrost and Kruger. Landdrost Van Staden asked Kgamanyane to 'keep his people together' in order for him to collect the taxes. At that same moment Kruger, in his capacity as Commandant-General, called the Kgafela away ${ }_{140}$ - seemingly to provide labourers to field-cornets Nicolaas Smit and Gert Botha. When they did not comply with this instruction, Kruger asked Field-Cornet H.P. Malan 'to investigate the case and punish the offender'.141 This led to the flogging incident.

In spite of the testimonies of H.P. Malan and Henri Gonin (1871 and 1879) which confirm that Malan was the one who flogged Kgamanyane in April 1870, rumours that Kruger did it or gave instructions to that effect seem to have been circulated. The origin of these rumours might have been Kgamanyane himself, who seems not to have made a distinction in his references to this incident between the person who actually administered the corporal punishment and the person he thought gave instructions for it.142 Even Gonin, who was located at Saulspoort, at first believed that Kruger flogged Kgamanyane.143 In his later correspondence on this matter, he confirmed that it was Malan. There is no reason to believe that Kruger would have instructed Malan beforehand to give Kgamanyane corporal punishment, since Malan was first to 'investigate' the matter. It appears that Landdrost Van Staden and Field-Cornet J.L.J. van Rensburg were also misled by this confusion. ${ }^{444}$ Even the 1871 Commission gave the impression in their report that in this regard they were either biased against Kruger or did not analyse the declarations before them thoroughly. While referring, for example, incorrectly in their report to Gonin's testimony as their source, they stated categorically that 'Gamanjan [Kgamanyane Pilane] ... according to the declarations made (see Declaration No. 17) [Gonin's declaration] was beaten several times by the Commandant General while a Field-Cornet also followed this example'.145 The Commission then, almost sarcastically, added: 'The Honourable Volksraad will see from the declaration by the Commandant General himself ... that he regards beating native kapiteins as against the Native Act.' 146

There appears to have been a strong anti-Kruger feeling at that stage among at least some of the members of the 1871 Commission. Gonin, for example, wrote after his testimony before the Commission:

One of the members of the Commission, when he heard testimony about some of the activities of our Commandant General, could not refrain himself from exclaiming that the heavens are crying out 'How can it still rain in Rustenburg' and another member 'If we do not get lung sickness [among the cattle] then I don't know!'147

Kruger was not a member of the 1871 Commission and did not attend its sittings, except when he testified on 17 and 18 October 1871.148 He therefore probably only became aware of the accusation against him when the report and documents of the Commission were tabled in the Volksraad. He then expressed the wish 'to clear himself of the accusations'.149 However, the way the debate on the report was handled in the Volksraad did not give Kruger the opportunity to discuss accusations against him. He was nevertheless able to defend himself very effectively when he was accused by J.R. Lys, the Member for Pretoria, that he enriched himself to the detriment of the state with regard to the land of the Bafokeng near Rustenburg.150 Eventually, at the end of the debate, when the possibility of the report being published, was discussed, Kruger 'expressed the wish that the matter first be investigated before it was published. He wished to counter accusations and in order to be able to defend himself, requested the protection from the Council.''151 The majority of the members agreed that 'the accusations which appear in the report had not yet been properly proven and most declarations were not sworn'.152

To arrive at a fair evaluation of Kruger's points of view on these matters, it is necessary now to undertake an analysis of his character and personality, as well as his vision 
for the future of the South African Republic. One of Kruger's biographers discusses two prominent characteristics that became apparent at an early stage of his life, namely Kruger's remarkable and consistent insistence on orderly government, with the enforcement of law and order, and his very strong religious convictions. Even as a young Assistant Field-Cornet of 25 years of age, he had already been, for example, one of the driving forces behind a petition in 1850 that demanded consistency and strong leadership in the Volksraad. He had also played a role two years later in the well-known reconciliation of A.W. Pretorius and A.H. Potgieter in Rustenburg, and in drafting the first constitution (1855-1858) of the Transvaal. During the period of civil war (1859-1864), Kruger was also undeniably the stabilising factor in a very trying time of Transvaal history.153 It was therefore to be expected that, in his dealings with Africans and in his attitude towards them, he would have given high priority to the stability of the Transvaal Republic.

Kruger's strong religious convictions also influenced his relationship with Africans. His Calvinist religious foundations were laid by his parents, but various other religious influences in his youth also played a role in awakening deep-rooted Christian convictions. One such influence was that of the missionary Daniel Lindley, an American Presbyterian, when Kruger and his parents met him in the Orange Free State during the 1840s. It would also appear that his personal spiritual experience as a young settler in the Transvaal, during which he spent a few days in seclusion in the veld, significantly affected him. These influences combined to foster, on the one hand, strict moral beliefs and, on the other, a religious enthusiasm to convert both blacks and whites to Christianity. Kruger's religious beliefs manifested themselves in various ways. For instance, he was involved in the building of the church in Rustenburg during the early 1850s, and also, during 1858-59, with the establishment of a congregation of the Reformed Church in that town; the Reverend Dirk Postma was their pastor. He also protected and supported the black evangelist, Dawid, who preached to African communities in the period before the arrival of missionaries in that vicinity. A few years later, Kruger commenced good relations with the Hermannsburg missionaries and encouraged them to carry out mission work in the vicinity of Rustenburg 154 and assisted the Dutch Reformed Church missionary, Henri Gonin, when in the 1860s he was looking for an African community among whom to settle. He eventually allowed Gonin to stay on his farm Saulspoort No. 269 without paying rent for as long as the Kgafela Bakgatla of Kgmanyane Pilane were there.155 His remarkable religious enthusiasm also impressed his seniors. It seems, for example, as if A.W. Pretorius confided at the end of his life in the much younger man (in his late twenties) with regard to personal religious issues.156

In August 1856, Kruger integrated his strong religious and political convictions in the advice that he offered M.W. Pretorius in an almost pious fashion, to adhere more strictly to the principles of Christianity.157 Twenty years later, in December 1876, Kruger, in response to requests to make himself available for the election of a state president in 1877, analysed the challenges and circumstances in the country on the eve of British annexation, observing:

The first task to be executed by the President refers to weighty and general matters, especially where the law does not make specific provisions, to consult the entire nation, guide the nation to promote unity in the nation, and then to act according to the voice of the nation. This is the main concern in our free Republic. Unity is strength, and where love is present the Lord commands [His blessing]. The State should be governed with complete justice and whites, as well as coloureds, should be administered with understanding. Justice uplifts a country and to comply with this in the strict sense of these words we need to turn our eyes to the mountains from which alone all our support is to be expected, namely: to the Lord of heaven and earth and we should not oppose Him, but should act in harmony with his will. This is revealed in his Word and his Word will free and protect us from the strongest enemies. Indeed, then we can lay claim to our independence and civil rights as a civilized State among the civilized Nations of the world, and then we can walk alongside other civilized States by means of just and peaceful policies.158

Kruger's straightforward and sometimes insensitive approach with regard to religions matters on occasion led to uncomfortable situations - such as his confrontation of E.J.P. Jorrissen concerning the latter's religious beliefs when they first met in March 1876.159 Despite this, W.J. Leyds, with whom Kruger worked very closely during the last part of his life, remembered him as a person who was not narrow-minded, but one who 'tends to be liberal, a developed person, in politics as well as in matters pertaining to religion'.160 
To Kruger's emphasis upon orderly government and firm religious beliefs, one could also add his determination to succeed in everything that he undertook, and his very active and enterprising approach to life in general. This must surely also have affected his relationship with Africans. His determination to succeed was, for example, illustrated in the way he got the better of the two very serious injuries he sustained in accidents, that is when a firearm exploded in his hand in 1845 in the vicinity of the Steelpoort and Spekboom River, and also in 1866 when he broke his leg at the knee-joint as a result of an accident involving a mule cart. The way he persevered as a Commandant-General in carrying out essential military operationsagainst hostile African communities in the outlying districts, despite half-hearted responses by burghers to their being called up for military service, is also indicative of this characteristic. The scope and success of Kruger's activities as a farmer and speculator in land are perhaps not well-known, but also afford an indication of his entrepreneurship, initiative and keen eye for business opportunities. During the period from the late 1850 s to the 1870s, he was involved in at least 26 land transactions, some of which were financially very lucrative. From the number of workers that he was employing by the early 1870 s, it is clear that he also carried out extensive farming activities on a number of these farms. According to the missionary H. L. Gonin, Kruger sometimes employed 50 to 60 African women on his lands in the immediate vicinity of Saulspoort. The situation was similar with regard to his farms in the vicinity of the Bafokeng, near Rustenburg. ${ }_{161}$ However, Kruger's enthusiasm and actions in this regard sometimes affected his African labourers negatively, when on occasion, he came across as strict, inflexible and unkind. ${ }_{162}$ The entrepreneurship and initiative he displayed up to the early 1870s nevertheless matured, becoming both more elaborate and more informed on a national level in the next ten years. For example, in 1882, as part of his campaign for the 1883 elections for state president, he articulated his points of view in this regard with remarkable clarity and vision:

As far as domestic policy is concerned, the first precondition is the development of the resources of the country in order to decrease our imports and increase our exports ... The primary resource is and remains agriculture, and this must be protected and promoted in the first place. The farmer is our real aristocrat, the landowner the strongest pillar of support of our national prosperity ...

I regard free trade as a second precondition for national prosperity, and it will therefore continue to be protected by me, especially taking care that the principle of concessions infringes on it as little as possible.

The manufacturing industry is a long-felt and recognised need. Why should our products be processed abroad and then be repurchased by us at very great expense, as is the case with wool, etc.? ... I will at all times, as much as possible without obstructing free trade, promote the manufacturing industry ... even if in the beginning it requires an apparent sacrifice.

For this it is, however, essential that our means of transport be improved, not only by opening and improving roads, but especially by a direct railway link with the sea, that is by a railway line from Pretoria to Delagoa Bay ...163

What we lack for the development of our resources and the establishment of essential public works is - capital. This has by no means escaped our attention ... It is our good fortune to lay the foundations of a substantial National Bank ...164

\section{$\mathrm{VI}$}

An analysis of Kruger's actions and points of view in the 1860s, 1870s and early 1880s presents interesting evidence of his entrepreneurship and realisation of the importance of modernisation in the context of the times at an early stage of his life. This must surely have influenced his relations with African communities in general and with his African labourers in particular. In this way, they also fit the profile of paternalistic relationships very well. In his explanation of how paternalism functions, Charles van Onselen emphasises the necessity for the patriarch to be seen as acting in a balanced manner towards his labourers:

A regime that relied on the stick to the exclusion of the carrot ceased, almost by definition, to be paternalistic. Thus for every assault on tenants there had to be compensating gifts and concessions if the long-term stability of the regime was to be ensured. A white 'father' was entitled to be severe with his black 'children' but, if he did not wish to become totally alienated from the christian mainstream that flowed through the community he had to be seen to be capable of acts of benevolence, care and generosity whenever the occasion demanded it.165 
In this regard Van Onselen also refers to Eugene D. Genovese's evaluation:

Paternalism and patriarchal ethos did not demand kindness, although they may have encouraged it: much less did they demand indulgence. A strong patriarch is not less so for being severe, so long as he accepts responsibility for the welfare of his children, as he and his society define such responsibility.166

Linking up with this belief was the 'shared commitment to christian values by landlord and tenant' which gave rise to their joint attendance at prayer meetings, for example, and their joint celebration of events such as births, weddings and funerals. 167

Many of the characteristics of paternalism, highlighted here by Van Onselen, were particularly visible in Kruger's relationship with Mokgatle Thethe and the Bafokeng who lived in his immediate vicinity. This functional relationship was sometimes interfered with by troublesome incidents. Positive features of the relationship include the 1866 observation by a visitor of the cordial relations between Kruger and Mokgatle; the way in which Kruger had taken trouble to accommodate the evangelist Dawid, the Hermannsburg missionaries and the Dutch Reformed missionary Gonin for the African communities in that area; and Kruger's insistence that the right of the Bafokeng to live on Beerfontein and Turffontein, from generation to generation, should be guaranteed in the deeds of sale.168 But these were counteracted by such matters as his making tough labour demands and an unpleasant incident concerning the reed seedlings and switch canes on one of the farms that he had sold to Christof Penzhorn and Mokgatle. It would seem as if Mokgatle had only indirectly been involved in this issue and that the real disagreement was between Kruger and Penzhorn. However, Kruger very unreasonably made Mokgatle responsible for the switch canes that Penzhorn had cut down for his own use.169 In Kruger's relations with Mokgatle and the Bafokeng, there was a fragile balance between the 'stick' and the 'carrot'. Typically of the paternalist, Kruger was seen as being 'capable of acts of benevolence, care and generosity' and had accepted 'responsibility for the welfare of his children'. The 'commitment to christian values' which Kruger and Mokgatle shared should also not be underestimated. It was indeed consistent with Kruger's strong religious beliefs that the Gospel be spread to African communities. It was therefore understandable that Kruger's son Pieter handed the Kruger family Bible to Mokgatle's son for safekeeping during the South African War (1899-1902).170

The fact that Kruger's relationships were paternalistic perhaps constituted the real difference between himself and the hardliners. Their very negative attitude towards Africans seems not to have allowed for 'acts of benevolence, care and generosity'. In many instances, they were also either explicitly opposed or indifferent to missionaries and mission work among African communities. Also, in contrast to the narrow-minded and one-sided self-confidence of the hardliners on race issues, it is striking that Kruger was apparently aware of how difficult it was to develop a viable race policy. He was prepared to admit that even by 1882 a sound foundation for a 'general native policy for the various states in South Africa' was still lacking. Kruger's characteristics as a moderniser and visionary are clearly visible in the following statement, in which he said:

Everyone who can grasp the difficulties of this matter will indeed agree with me if I proclaim the man who can put forward an adequate solution to it as the greatest benefactor of South Africa. This man has perhaps yet to be born ... My hope is that in the future, through the blessing of God, matters will have developed to such an extent that order, industry and godliness will also make the native a happy and satisfied subject of the South African Republic.171 


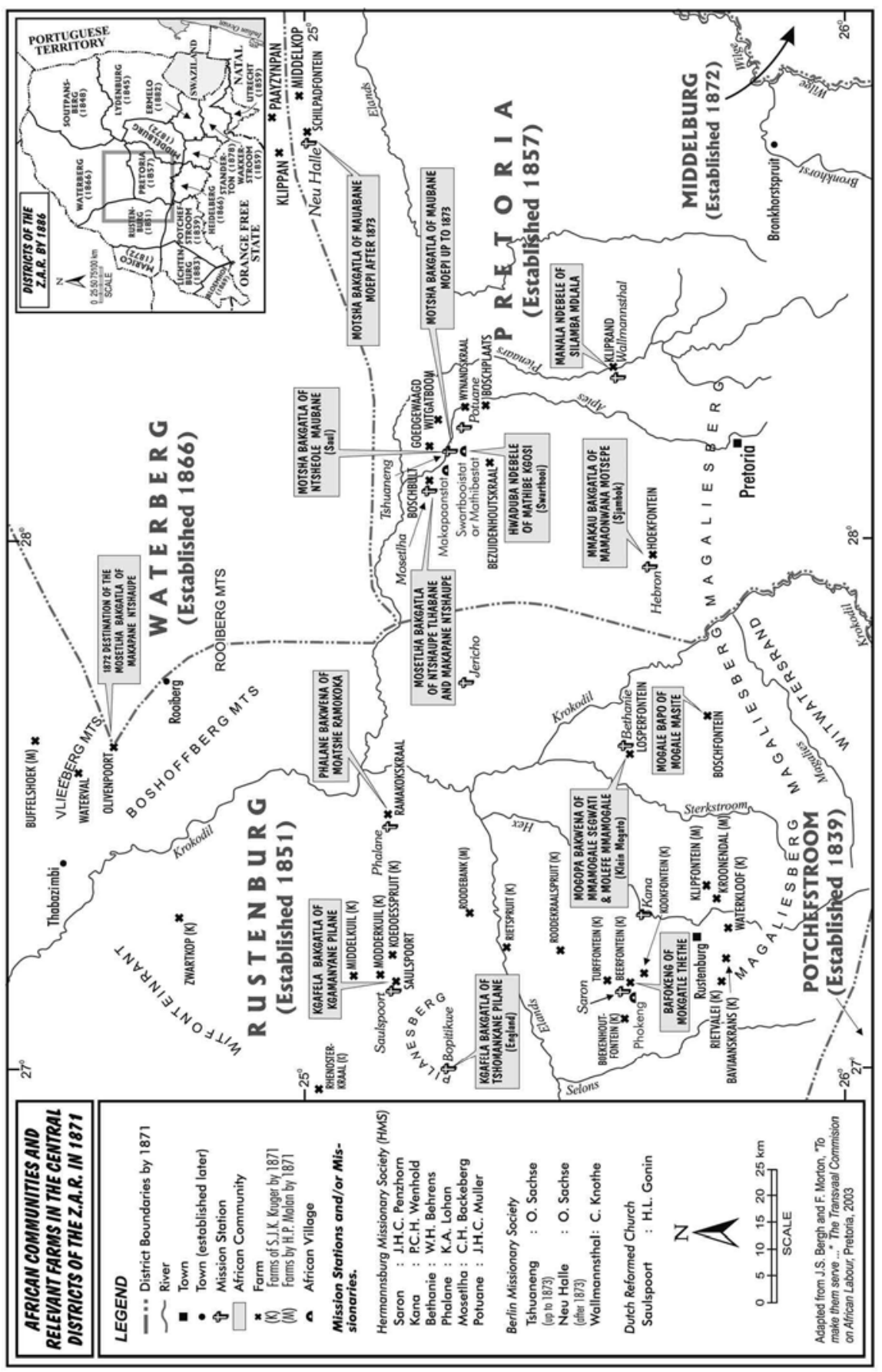


*. An earlier version of this article was presented at the Biennial Conference of the Historical Association of South Africa in Pretoria, June 2006. I wish to express my appreciation to Charles van Onselen for his constructive comments and suggestions for improving the earlier version.

1. For the purpose of identifying the so-called 'hardliners' and 'moderates' for this investigation, the points of view expressed in the testimonies and correspondence before the 1871 Transvaal Commission on African Labour, as well as opinions voiced when the report of the Commission was tabled in the Volksraad, were taken into consideration. It should, however, be remembered that most of those who testified before the Commission were inhabitants of the districts of Pretoria and Rustenburg. Only three persons of the District of Lydenburg and one each of the districts of Utrecht and Zoutpansberg testified.

2. J.W. Cell, The Highest Stage of White Supremacy: The Origins of Segregation in South Africa and the American South (Cambridge, 1982), 47.

3. B.K. Mbenga, 'Forced Labour in the Pilanesberg: The Flogging of Chief Kgamanyane by Commandant Paul Kruger, Saulspoort, April 1870', Journal of Southern African Studies, 23, 1 (Mar. 1997), 127-40.

4. In a recent, thorough and very useful analysis of the various publications dealing with S.J.P. Kruger, the historian Pieter de Klerk has arrived at the conclusion that, in the course of more than a century, individual authors have offered radically different assessments of Kruger and his points of view; also, many of these authors were significantly influenced by their own times. Very few of them utilised Kruger's documents and speeches in a comprehensive and systematic manner: P. de Klerk, 'Die Politieke Beskouing van Paul Kruger - Interpretasies oor 'n Tydperk van 125 Jaar', Tydskrif vir Geesteswetenskappe, 46, 2 (June 2006), 171-83.

5. S. Trapido, 'Reflections on Land, Office and Wealth in the South African Republic, 1850-1900', in S. Marks and A. Atmore, eds, Economy and Society in Pre-Industrial South Africa (London, 1980), 350-68; S. Trapido, 'The South African Republic: Class Formation and the State, 1850-1900', Societies of Southern Africa in the 19th and 20 th Centuries, 3 (London, 1977) 53-65; P. Delius, The Land Belongs to Us: The Pedi Polity, the Boers and the British in the Nineteenth-Century Transvaal (Johannesburg, 1983); R. Wagner, 'Zoutpansberg: The Dynamics of a Hunting Frontier, 1848-67', in Marks and Atmore, Economy and Society, 313-49; T.J. Keegan, Rural Transformations in Industrial South Africa: The Southern Highveld to 1914 (Johannesburg, 1986); A.J. Christopher, 'Official Land Disposal Policies and European Settlement in Southern Africa 1860-1960, Journal of Historical Geography, 9, 4 (1983); F.J. Potgieter, 'Die Vestiging van die Blanke in Transvaal (1837-1886) met Spesiale Verwysing na die Verhouding tussen die Mens en die Omgewing', Archives Year Book for South African History, II (Pretoria, 1953); W.A. Stals, 'Die Kwessie van Naturelle-Eiendomsreg op Grond in Transvaal, 1838-1884', Archives Year Book for South African History (Pretoria, 1972).

6. De Klerk, 'Politieke Beskouing van Paul Kruger'.

7. J.S. Bergh and F. Morton, 'To Make Them Serve...': The 1871 Transvaal Commission on African Labour (Pretoria, 2003).

8. See, for example, Stals, 'Die Kwessie van Naturelle-Eiendomsreg', 13-14; J.S. Bergh, 'Die Berlynse Sendinggenootskap in Pretoria en Omgewing, 1866-1881' (MA thesis, University of South Africa, 1973), 105ff.; Delius, The Land Belongs to Us, 151-3.

9. F. Jeppe and J.G. Kotzé, eds, De Locale Wetten der Zuid-Afrikaansche Republiek, 1849-85 (Pretoria, 1887), 97: Instructie voor Veldcornetten, 17 Sep. 1858.

10. J.H. Breytenbach and D.C. Joubert, eds, South African Archival Records, Transvaal No. 5 (Pretoria, 1953), 271-4: Bylae 70/1864, Ordonnantie ter Voorkoming van Landloopery, Dievery en Ander Ongeregeldheden ... 28 Nov. 1864; Ibid., 423-6: Bylae 105 van 1865/66, Gouvernements Kennisgewing van Wet ter Voorkoming van Landloopery, Dievery en Ander Ongeregeldheden.. 13 July 1866; Jeppe and Kotzé, Locale Wetten 1849-85, 378-83: Wet No. 9, 1870, Ter Voorkoming ... 27 July 1870

11. Jeppe and Kotzé, Locale Wetten 1849-85, 378-82: Wet No. 9, 1870, Ter Voorkoming ... 27 July 1870.

12. Transvaal Archives (hereafter TA), Archives of the State Secretary (hereafter SS) 139, Supplementary documents for 1871, No. Supl. 90/1871, 307-8: Petitions to the Volksraad re African Labour, 1868-1871. The documents of the 1871 Transvaal Commission were translated and published in Bergh and Morton, 'To Make Them Serve ...'. In this article, however, references are made to the original documents in the Transvaal Archives.

13. TA, SS 139, Supplementary documents for 1871, No. Supl. 82/1871, 259: A. Merensky, 
Memorandum, 17 Oct. 1871.

14. TA, SS 139, Supplementary documents for 1871, No. Supl. 91/1871, 310: Testimony of S.T. Prinsloo, 11 Sep. 1871.

15. De Volksstem (Byvoegsel), 10 Oct. 1877; TA, Archives of the Superintendent of Natives (hereafter SN) 1 A: R. Lys to Colonial Secretary, 16 Apr. 1879; see also Delius, The Land Belongs to Us, 66-7.

16. See TA, Plaas requestenregister (hereafter RAK) 2433.

17. Potgieter, 'Die Vestiging van die Blanke in Transvaal', 107.

18. Ibid., 93-5.

19. TA, SS 139, Supplementary Documents for 1871, No. Supl. 107/1871 and 108/1871, 359 and 364: Testimonies of H. Gonin, 28 Sep. 1871 and C. Penzhorn, 29 Sep. 1871.

20. Berliner Missionsberichte (1867), 68.

21. C. Bundy, The Rise and Fall of the South African Peasantry (Cape Town, 1988).

22. TA, SS 8615, Letter Book (hereafter BB) 1769/66: H. van der Linden to T. Erasmus, 28 Sep. 1866; TA, Landdrost Pretoria 32: W. Skinner to Andries Maubane, 12 Jan. 1872; TA, Landdrost Pretoria 34: R. Lys to Zwartbooi, 8 July 1879 and to Salamba, 8 July 1879.

23. TA, SS 19, R1960/58: A.F. du Toit to President, 15 Mar. 1858; TA, SS 8616, BB 715/67: M.J. Viljoen to Makapan, 13 Dec. 1867; TA, SS 8611, BB 122/60: J.H.M. Struben to A.P. van der Walt, 29 May 1860; TA, SS 100, R 783/68: H. Backeberg to M.W. Pretorius, 9 June 1868; TA, Landdrost Pretoria 32: Landdrost to Salamba, 22 Oct. 1874; TA, SS 448, R 3409/80: S. Melville to Colonial Secretary, 18 Aug. 1880.

24. TA, Landdrost Pretoria 2: S. Begemann to C. Moll, 14 May 1866.

25. TA, SS 179, R 1945/74: H. Henshall to T. Burgers, 21 Dec. 1874.

26. TA, SN 102: H. Shepstone to Engineer Officer, 19 Dec. 1879.

27. J.S. Bergh, "'To Make Them Serve”: The 1871 Transvaal Commission on African Labour as a Source for Agrarian History', History in Africa, 29 (2002), 55.

28. Ibid., 55-6; Staats Courant der Zuid-Afrikaansche Republiek (Government Gazette), No. 407 (1872): Minutes of the Volksraad, 13 Nov. 1871, article 344.

29. Bergh, 'To Make Them Serve', 57.

30. TA, SS 139, Supplementary Documents for 1871, No. Supl. 92/1871, 96/1871, 107/1871, 108/1871, 109/1871 and 113/1871, 315-16, 327, 336, 359-60, 363-4, 370, 385, 388:

Testimonies of O.C. Weeber, P.J. van Staden, H.C. Gonin, C. Penzhorn, P.J. van Staden and J.L. Jansen van Rensburg, 13 Aug. 18, 28 and 29 Sep., 2 and 5 Oct. 1871.

31. Ibid., No. Supl. 91/1871, 313: Testimony of S.T. Prinsloo, 11 Sep. 1871.

32. Ibid., No. Supl. 101/1871, 346: Testimony of T. Erasmus, 22 Sep. 1871.

33. Ibid., No. Supl. 101/1871, 376: Testimony of H.P. Malan, 3 Oct. 1871.

34. Ibid., 374.

35. Ibid., No. Supl. 91/1871, 101/1871, 110/1871, 114/1871, 310-15, 344-5, 373-4, 390-1: Testimonies of S.T. Prinsloo, T. Erasmus, H.P. Malan and G. Brits, 11 and 22 Sep., 3 and 5 Oct. 1871.

36. TA, RAK 3015-3023, Farm Registers for the District of Rustenburg (see later for a list of the farms). In this article the old/original farm numbers are used.

37. Ibid., Wonderboom No. 311, Rooifontein No. 378, Kromdraai No. 459.

38. Ibid., Wolvenkraal No. 560, Klippan No. 446.

39. Ibid., various farms. 
40. Ibid. No farms have been traced for 1871 in the Farm Registers.

41. Ibid., Paardekraal No. 388 (Section A), Hartebeestlaagte No. 724 and Elandsfonrein No. 510.

42. Ibid., Welgevonden No. 69, Nooitgedacht No. 71, Geluk No. 72, Rooisloot No. 513 en Waterval No. 544.

43. Ibid., Elandspoort No. 193 (Section A II(a)), Loskop No. 197, Bultfontein No. 212 (Section B), Hondekraal No. 403, Welgegund No. 481 (Section B).

44. Ibid., Geluk No. 234.

45. Ibid., Klippan No. 331, Middelkop No. 332.

46. Christopher, 'Official Land Disposal Policies', 369-83; Trapido, 'Reflections on Land, Office and Wealth', 352-5; Delius, The Land Belongs to Us, 128-30; J.H. Breytenbach, ed., South African Archival Records, Transvaal No. 4 (Pretoria, 1952), 79: Minutes of the Volksraad, 28 Sep. 1860, article 149; Bergh, 'To Make Them Serve', 45-8.

47. J.S. Bergh, "'(To) Reserve to the Native Tribes Such Locations as They May Be Fairly and Equitably Entitled To": The Transvaal Location Commission (1881-1899)', South African Historical Journal, 54 (2005), 3-4.

48. Delius, The Land Belongs to Us, 131-4.

49. TA, SS 139, Supplementary Documents for 1871: Testimonies before the Commission, Sep. Oct. 1871.

50. Ibid., No. Supl. 101/1871, 346: Testimony of T. Erasmus, 22 Sep. 1871. Erasmus was a fieldcornet to the north of Pretoria in the vicinity of the Apies River and had an interest, with a group of farmers, in the labour of the Motsha Bakgatla of that area. The Motsha were living on land made available to them by these farmers in exchange for their labour, but by the early 1870 s widespread discontent had developed between them. (See below.)

51. Ibid., No. Supl. 114/1871, 391: Testimony of G. Brits, 5 Oct. 1871.

52. Staats Courant der Zuid-Afrikaansche Republiek (Government Gazette), No. 407 (1872): Minutes of the Volksraad, 13 Nov. 1871, article 344.

53. Ibid.

54. Ibid., 11-13 Nov. 1871, articles 342-6 (Remarks by S.J. Meintjes, M. de Vries and T.F. Dreyer).

55. Ibid., 13 Nov. 1871, article 344.

56. Ibid.

57. Ibid.

58. Ibid.

59. Ibid., 14 Nov. 1871, article 346/7.

60. TA, SS 139, Supplementary Documents for 1871, No. Supl. 91/1871 and 101/1871, 310, 345: Testimonies of S.T. Prinsloo and T. Erasmus, 11 and 22 Sep. 1871.

61. Staats Courant, No. 407 (1872): Minutes of the Volksraad, 29 Nov. 1871, article 400.

62. J.S. Bergh, “'De Ordonnantie (is) Eene Doode Letter" - Die 1871 Transvaalse Ondersoek na die Handel in Vuurwapens met Swartes', Historia, 46, 2 (Nov. 2001), 338-9.

63. TA, Archives of the Volksraad (hereafter EVR) 214, No. 78, 355: Recommendations of the Commission, 7 Nov. 1871, No. E.

64. J.S. Bergh, Geskiedenisatlas van Suid-Afrika: Die Vier Noordelike Provinsies (Pretoria, 1999), chapters 6.1-6.5.

65. Staats Courant, No. 409 (1871): Minutes of the Volksraad, 29 Nov. 1871, article 400.

66. TA, SS 139, Supplementary Documents for 1871, No. Supl. 116/1871, 396: Testimony of S.J.P. Kruger, 17 Oct. 1871. 
67. Jeppe and Kotzé, Locale Wetten 1849-85, 381: Wet No. 9, 1870, Ter voorkoming ... 27 July 1870.

68. Bergh, 'To Make Them Serve', 52-3, 60.

69. TA, SS 139, Supplementary Documents for 1871, No. Supl. 107/1871 and 108/1871, 359, 364 : Testimonies of H.L. Gonin and C. Penzhorn, 28 and 29 Sep. 1871.

70. J.S. Bergh, "'We Must Never Forget Where We Come From": The Bafokeng and their Land in the 19th Century Transvaal', History in Africa, 32 (2005), 109-10.

71. Anonymous traveller's account in the Natal Mercury, 11 Dec. 1866, quoted in F. Morton, 'Captive Labour in the Western Transvaal after the Sand River Convention', in E.A. Eldredge and F. Morton, Slavery in South Africa: Captive Labour on the Dutch Frontier (Pietermaritzburg, 1994), 176.

72. TA, SS 139, Supplementary Documents for 1871, No. Supl. 116/1871, 401: Testimony of S.J.P. Kruger, 17-18 Oct. 1871.

73. Ibid.

74. S.P. Engelbrecht, Thomas Francois Burgers. 'n Lewenskets (Pretoria, 1933), 371.

75. TA, SS 139, Supplementary Documents for 1871, No. Supl. 116/1871, 398: Testimony of S.J.P. Kruger, 17-18 Oct. 1871. For Kruger's comments to the Volksraad in this regard, see also Minutes of the Volksraad, 13 Nov. 1871, article 344.

76. Ibid.

77. TA, Archives of the Executive Council (hereafter UR) 2, 583-4: Minutes of the Executive Council, 21 Jan. 1868, article 14.

78. D.C. Joubert, ed., South African Archives Records, Transvaal No. 8 (Pretoria, 1989), 28-9: Minutes of the Volksraad, 6 Oct. 1868, articles 111 and 112.

79. TA, Archives of the Volksraad (hereafter EVR) 214, No. 78, 354: Recommendations of the Commission, 7 Nov. 1871, No. A.

80. Staats Courant, No. 407 (1872): Minutes of the Volksraad, 14 Nov. 1871, articles 346/7.

81. Ibid., 13 Nov. 1871, article 344.

82. Ibid.

83. TA, RAK 2433, Z.J. de Beer, Beerfontein, 30 July 1849, no. 462, folio 42.

84. Bergh, 'To Make Them Serve', 44.

85. TA, EVR, Minutes of the Volksraad, 11 June 1891, article 374, 145-6.

86. TA, SS 1144, R 6352/85, 79-80: Deed of Sale between S.J.P. Kruger and C. Penzhorn, 4 Nov. 1868; Ibid., 77-8: Deed of Transfer No. 8133, Turffontein, and Deed of Transfer No. 8134, Beerfontein, 18 July 1871; D.W. Kruger, Paul Kruger, vol. I (Johannesburg, 1961), 77.

87. Bergh, Geskiedenisatlas van Suid-Afrika, 176-80, 188-91.

88. TA, SS 139, Supplementary Documents for 1871, No. Supl. 116/1871, 397-8: Testimony of S.J.P. Kruger, $17-18$ Oct. 1871.

89. TA, SS 79, R 878/66, 244-7: Report of the Commandant-General, 30 Aug. 1866.

90. TA, SS 139, Supplementary Documents for 1871, No. Supl. 108/1871, 368: Testimony of C. Penzhorn, 29 Sep. 1871.

91. F.P. Smit, Die Staatsopvattinge van Paul Kruger (Pretoria, 1951), 58-9.

92. TA, RAK 3015-3023, Farm Registers for the District of Rustenburg: Waterkloof No. 4, Baviaanskrans No. 288, Rietvalei No. 824, Boekenhoutfontein No. 336 and Kookforntein No. 337.

93. Ibid.: Turffontein No. 297 and Beerfontein No. 432. 
94. Ibid.: Rietspruit No. 419 and Roodekraalspruit No. 592.

95. Ibid.: Middelkuil No. 564, Modderkuil No. 565 and Koedoesspruit No. 572.

96. Ibid.: Rhenosterkraal No. 563.

97. Ibid.: Zwartkop No. 355.

98. Ibid.: Kroonendal No. 177 and Klipfontein No. 538.

99. Ibid.: Roodebank No. 492.

100. Ibid.: Buffelshoek No. 799.

101. Ibid.: Losperfontein No. 119, Boschfontein No. 193, Doornpoort No. 251, Kleindoornspruit No. 255, Saulspoort No. 269, Beestkraal No. 296, Welgevonden No. 351, Zoutpansdrift No. 359 , Klipfontein No. 538, Waterval No. 544 and Palmietfontein No. 551.

102. Ibid.: Rietfontein No. 291, Kafferskraal No. 890, Welgevonden Nor. 267 and Reinkoyalskraal No. 333.

103. Ibid.: Beerkraal No. 545.

104. Ibid.: Buffelspan No. 588, Ruighoek No. 426 and Leeuwdrift No. 719.

105. TA, SS 139, Supplementary Documents for 1871, No. Supl. 108/1871, 364: Testimony of C. Penzhorn, 29 Sep. 1871.

106. Ibid., No. Supl. 108/1871 and 115/1871, 364-5, 394: Testimonies of C. Penzhorn, 29 Sep. 1871 and Mokgatle Thethe, 27 Sep. 1871.

107. Ibid., No. Supl. 108/1871, 367: Testimony of C. Penzhorn, 29 Sep. 1871.

108. TA, RAK 3015-3023, Farm Registers for the District of Rustenburg: Saulspoort No. 269.

109. TA, SS 139 Supplementary Documents for 1871, No. Supl. 107/1871, 359: Testimony of H. Gonin, 28 Sep. 1871.

110. Ibid., No. Supl. 96/1871, 328-30: Testimony of P.J. van Staden, 19 Sep. 1871.

111. B. Spoelstra, 'Hercules Philippus Malan', in C.J. Beyers, ed., Dictionary of South African Biography, vol. IV (Pretoria, 1981), 339-40.

112. C. Sonntag, My Friend Maleboch, Chief of the Blue Mountains (Pretoria, n.d.), 119, 125-6, 9.

113. TA, SS 139 Supplementary Documents for 1871, No. Supl. 83/1871, 253-6: Renewal of Contract by A.[P.] van der Walt and Mahep [Moepi Maubane] and by his successor Andries [Maubane Moepi], 1 Nov. 1870; Ibid., 363-5: Andries Maubane to Volksraad, 4 Dec. 1870; Ibid., No. Supl. 85/1871, 270-7: S.J.P. Kruger to President and Executive Council, 20 Dec. 1871; Ibid., Supl. 103/1871, 349-51: Testimony of David, 25 Sep. 1871; Ibid., Supl. 104/1871, 351-2: Testimony of Maubane Moepi, 25 Sep. 1871; Ibid., Supl. 106/1871, 355-8: Testimony of Otto Sachse, 28 Sep. 1871; TA, RAK 2989-300: Farm Registers for the District of Pretoria: Boschplaas No. 507, Witgatboom No. 62 and Wynandskraal No. 154.

114. TA, SS 8611, BB 134/63: J.H. Visagie to F.K. Maré, 7 Apr. 1863; TA, SS 154, R324/73: J.P. Botha and 24 others to President and Executive Council, 1 Mar. 1873.

115. TA, SS 139 Supplementary Documents for 1871, No. Supl. 101/1871, 343: Testimony of T. Erasmus, 22 Sep. 1871.

116. Ibid., No. Supl. 91/1871, 310, 313-14: Testimony of S.T. Prinsloo, 11 Sep. 1871.

117. Ibid., 312.

118. TA 156, R 673/73, 187: O. Sachse to President and Executive Council, 10 May 1873; Berliner Missionsberichte (1875), 187.

119. TA, SS 158, R 1105/73, 24-5: H.W. Behrens to N.J.R. Swart, 23 July 1873; TA, SS 139 Supplementary Documents for 1871, No. Supl. 113/1871, 386: Testimony of J.L.J. van Rensburg, 5 Oct. 1871.

120. TA, SS 139 Supplementary Documents for 1871, No. Supl. 96/1871, 113/1871 and 114/1871, 331-2, 386-7, 390-2: Testimonies of P.J. van Staden, J.L.J. van Rensburg and G. Brits, 19 Sep. 
1871 and 5 Oct. 1871.

121. Ibid., Supl. 114/1871, 390: Testimony of G. Brits, 5 Oct. 1871.

122. Ibid., Supl. 110/1871, 374: Testimony of H.P. Malan, 3 Oct. 1871.

123. Ibid., Supl. 107/1871, 358: Testimony of H.L. Gonin, 28 Sep. 1871.

124. TA, SN I: H. Gonin to H.C. Shepstone, 15 Aug. 1879.

125. TA, SS 139 Supplementary Documents for 1871, No. Supl. 111/1871, 380: Testimony of D.J. van der Merwe, 4 Oct. 1871.

126. Archives of the Dutch Reformed Church (hereafter DRC), Saulspoort 15/7/2(A), 164-6: H. Gonin to Dutch Reformed Church, 11 Sep. 1870; TA, SS 131, R 166/71, 347-9: S.J.P. Kruger to President and Executive Council, 1 Feb. 1871.

127. TA, SS 139 Supplementary Documents for 1871, No. Supl. 96/1871, 329-31: Testimony of P.J. van Staden, 19 Sep. 1871.

128. Ibid., No. Supl. 85/1871, 270-7: S.J.P. Kruger to the President and Executive Council, 20 Dec. 1870.

129. TA, SS 126, R1151/70, 276-8: S.J.P. Kruger to President and Executive Council, 7 Oct. 1870.

130. TA, RAK 3015-3023, Farm Registers for the District of Rustenburg: Saulspoort No. 269, 4 Aug. 1869; Archives of the DRC, Saulspoort 15/7/2(A), 125-30: H. Gonin to Dutch Reformed Church, 12 Jan. 1869.

131. TA, SS 139 Supplementary Documents for 1871, No. Supl. 110/1871, 375: Testimony of H.P. Malan, 3 Oct. 1871; Henri Gonin confirmed that Kgamanyane indulged in excessive drinking. On 25 September 1867 he wrote that Kgamanyane 'is geheel en al een slaaf des dranks': Archives of the DRC, Saulspoort 15/7/2(A), 89: H. Gonin to Dutch Reformed Church, 25 Sep. 1867.

132. Mbenga, 'Forced Labour in the Pilanesberg', 128-9.

133. Ibid., 138.

134. Ibid., 128-9.

135. J. Tosh and S. Lang, The Pursuit of History (London, 2006), 324-33.

136. Mbenga, 'Forced Labour in the Pilanesberg', 128-9.

137. Archives of the DRC, Saulspoort 15/7/2(A), 79: Mrs T. Gonin to Dutch Reformed Church, 1 Oct. 1866.

138. TA, SS 139 Supplementary Documents for 1871, No. Supl. 110/1871, 373-4: Testimony of H.P. Malan, 3 Oct. 1871.

139. Archives of the DRC, Saulspoort 15/7/2(A), 131-2: H. Gonin to Dutch Reformed Chruch, 6 Mar. 1869.

140. TA, SS 139 Supplementary Documents for 1871, 129-30: No. Supl. 96/1871, 327-8: Testimony of P.J. van Staden, 19 Sep. 1871.

141. Ibid., No. Supl. 110/1871, 374: Testimony of H.P. Malan, 3 Oct. 1871.

142. See, for example, ibid., No. 96/1871 and No. 113/1871, 328-9, 387: Testimonies of P.J. van Staden, 19 Sep. 1871 and J.L.J. van Rensburg, 5 Oct. 1871.

143. Archives of the DRC, Saulspoort 15/7/2(A), 164-6: H. Gonin to Dutch Reformed Church, 11 Sep. 1870.

144. TA, SS 139 Supplementary Documents for 1871, No. Supl. 96/1871 and 113/1871, 328-9, 387 : Testimonies of P.J. van Staden and J.L.J. van Rensburg, 19 Sep. 1871 and 5 Oct. 1871.

145. TA, EVR 214, No. 78, 341-2: Report of the Commission, 7 Nov. 1871, No. 12. In fairness to the Commission it must, however, be stated that in the testimony of at least P.J. van Staden it was alleged that Kgamanyane was flogged on two occasions: see TA, SS 139 Supplementary Documents for 1871, No. Supl. 96/1871, 129-30: Testimony of P.J. van Staden, 19 Sep. 1871. 
146. Ibid., No. 14; Also see TA, SS 139 Supplementary Documents for 1871, No. Supl. 116/1871, 398: Testimony of S.J.P. Kruger, 17-18 Oct. 1871.

147. Archives of the DRC, Saulspoort 15/7/2(A), 176-7: H. Gonin to Dutch Reformed Church, 6 Oct. 1871. The cordial relationship between Gonin and Kruger seems to have turned sour after Kruger coerced Kgamanyane and Gonin in 1868/9 into buying the farm Saulspoort No. 269. This was despite an earlier promise by Kruger that he would not sell the farm and that he even put it in his will that the Kgafela Bakgatla should not be forced to leave the farm. Also, that Gonin could live on the farm without paying rent: Archives of the DRC, Saulspoort 15/7/2(A), 60-1, 125-30: H. Gonin to Dutch Reformed Church, 2 May 1866 and 12 Jan. 1869.

148. TA, SS 139 Supplementary Documents for 1871, No. Supl. 89/1871, 285-306: Minutes of the Meetings of the Commission, 11 Sep. $1871-1$ Nov. 1871

149. Staats Courant No. 407 (1872), Minutes of the Volksraad, 10 Nov. 1871, articles 337 and 338.

150. Ibid., 13 Nov. 1871, article 344.

151. Ibid., 30 Nov. 1871, article 412

152. Ibid.

153. D.W. Kruger, Paul Kruger, I, 37-8, 43, 44, 60-73.

154. Ibid., 10-11, 19, 27, 28-9, 47-8, 56-60, 81-2; S.J.P. Kruger, Memoirs, vol. I (London, 1902) 17-18; J.F. van Oordt, Paul Kruger en de Opkomst van de Zuid-Afrikaansche Republiek (Amsterdam, 1898), 47 and footnote 1.

155. Archives of the DRC, Saulspoort 15/7/2(A), 19-20, 26-7, 29, 54-7, 60-1: H. Gonin to the Dutch Reformed Church, 13 June 1862, 9 Aug. 1862, 5 Sep. 1862, 6 Mar. 1866 and 2 May 1866.

156. S.J.P. Kruger, Memoirs, I, 61.

157. D.W. Kruger, Paul Kruger, I, 46-7.

158. Staatscourant der Z.A. Republiek, No. 666, 3 Jan. 1877, 2: S.J.P. Kruger, Answer to requests to make himself available as a candidate for the election of State President, 22 Dec. 1876. In another response to requests to make himself available for the election, published in the Afrikaanse Patriot, Kruger directly blames President Burgers for the unsatisfactory state the Republic was in at that stage: '... but see now, when Burgers is President - he knows no Sabbath; he rides through every part of the country on Sundays; of Church and religion he knows nothing.' However, M. Nathan, Paul Kruger: His Life and Times (Durban, 1944), 104-5, speculates that the editor of the Afrikaanse Patriot, the Reverend S.J. du Toit, had a hand in this version. J. Fisher, Paul Kruger (London, 1973), 50, also quotes this version but does not cite any source for it. H. Giliomee, The Afrikaners. Biography of a People (Cape Town, 2006), 229, adopts this quotation from Fisher.

159. E.J.P. Jorissen, Transvaalsche Herinneringen 1876-1896 (Amsterdam, 1897), 16.

160. K. van Hoek, Gesprekke met Dr. W.J. Leyds (Pretoria, 1939), 35, quoted by Smit, Die Staatsopvattinge van Paul Kruger, 81.

161. D.W. Kruger, Paul Kruger, I, 86-7, 90-1; S.J.P. Kruger, Memoirs, I, 33-7; TA, SS 139, Supplementary Documents for 1871, No. Supl. 107/1871, 359 and 364: Testimonies of H. Gonin, 28 Sep. 1871 and C. Penzhorn, 29 Sep. 1871; Bergh, 'To Make Them Serve', 46.

162. See, for example, TA, SS 139 Supplementary Documents for 1871, No. Supl. 111/1871 and 113/1871: Testimonies of D.J. van der Merwe and J.L.J. van der Walt, 4 and 5 Oct. 1871. See also H. Gonin's allegations that Kruger coerced Kgamanyane and himself into buying Saulspoort No. 269 in 1869: Archives of the DRC, Saulspoort 15/7/2(A), 125-30: H. Gonin to Dutch Reformed Church, 12 Jan. 1869.

163. TA, SS 710, R4735/82, 159-60: S.J.P. Kruger, Answer to requests to make himself available as a candidate for the election of State President, n.d. (1882). The intellectual maturity and depth of vision of Kruger in this response can inter alia be ascribed to his exposure in the United Kingdom and Europe to a wide variety of gifted and influential individuals, as well as to other important stimuli at the end of the 1870s and beginning of the 1880s. It is also possible that at least some of the ideas of the well-known Dutch theologian and statesman, Abraham Kuyper, could have reached Kruger via S.J. du Toit: see, for example, B. Spoelstra, Die Doppers in SuidAfrika 1760-1899 (Johannesburg, 1963), 183 and footnote 117.

164. TA, SS 750, R6475/82, 188: S.J.P. Kruger, Answer to requests to make himself available as a 
candidate for the election of State President, 23 Nov. 1882.

165. C. van Onselen, 'The Social and Economic Underpinning of Paternalism and Violence on the Maize Farms of South-Western Transvaal, 1900-1950', Journal of Historical Sociology, 5, 2 (June 1992), 143.

166. Ibid., 142.

167. Ibid., 143-4.

168. See above.

169. This incident took place when Kruger sold his farm Beerfontein No. 432 to Christof Penzhorn and Mokgatle Thethe at the end of the 1860s and when Penzhorn agreed to keep the reed seedling plants on the farm for Kruger until the next winter. In exchange Penzhorn would then have received one plant from Kruger. Kruger, however, apparently did not remove the plants during the next winter and when the new shoots matured Penzhorn cut them off for his own use. When Kruger learnt that Penzhorn had already removed the shoots, he held Mokgatle responsible since he did not take care of the plants. He fined Mokgatle and eventually Penzhorn had to advance the money to Mokgatle to pay Kruger: TA, SS 139, Supplementary Documents for 1871, No. Supl. 96/1871 and 108/1871, 334-6, 365-6: Testimonies of P.J. van Staden and C. Penzhorn, 19 and 29 Sep. 1871.

170. C.A.R. Schulenburg, 'Familiebybel van Staatspresident S.J.P. Kruger', South African Journal of Cultural History, 9 (1995), 135.

171. TA, SS 750, R6475/82, 184-5: S.J.P. Kruger, Answer to requests to make himself available as a candidate for the election of State President, 23 Nov. 1882. 